\title{
Impact of climate change on groundwater point discharge: backflooding of karstic springs (Loiret, France)
}

\author{
E. Joigneaux ${ }^{1,2}$, P. Albéric ${ }^{1}$, H. Pauwels ${ }^{2}$, C. Pagé ${ }^{3}$, L. Terray ${ }^{3}$, and A. Bruand ${ }^{1}$ \\ ${ }^{1}$ Université d'Orléans - INSU/CNRS, UMR6113, Institut des Sciences de la Terre d'Orléans (ISTO), 1A rue de la Férolerie, \\ F45071 - Orléans Cedex 2, France \\ ${ }^{2}$ BRGM, Service Eau, 3 Avenue Claude Guillemin, BP36009, 45060 - Orléans Cedex 2, France \\ ${ }^{3}$ Sciences de l'Univers au CERFACS, URA 1875, CERFACS/CNRS, 42 Avenue Gaspard Coriolis, 31057 Toulouse \\ Cedex 01, France
}

Received: 1 February 2011 - Published in Hydrol. Earth Syst. Sci. Discuss.: 2 March 2011

Revised: 29 June 2011 - Accepted: 28 July 2011 - Published: 4 August 2011

\begin{abstract}
Under certain hydrological conditions it is possible for spring flow in karst systems to be reversed. When this occurs, the resulting invasion by surface water, i.e. the backflooding, represents a serious threat to groundwater quality because the surface water could well be contaminated. Here we examine the possible impact of future climate change on the occurrences of backflooding in a specific karst system, having first established the occurrence of such events in the selected study area over the past 40 years. It would appear that backflooding has been more frequent since the 1980s, and that it is apparently linked to river flow variability on the pluri-annual scale. The avenue that we adopt here for studying recent and future variations of these events is based on a downscaling algorithm relating large-scale atmospheric circulation to local precipitation spatial patterns. The largescale atmospheric circulation is viewed as a set of quasistationary and recurrent states, called weather types, and its variability as the transition between them. Based on a set of climate model projections, simulated changes in weathertype occurrence for the end of the century suggests that backflooding events can be expected to decrease in 2075-2099. If such is the case, then the potential risk for groundwater quality in the area will be greatly reduced compared to the current situation. Finally, our results also show the potential interest of the weather-type based downscaling approach for examining the impact of climate change on hydrological systems.
\end{abstract}

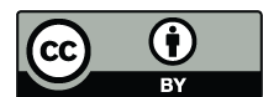

Correspondence to: E. Joigneaux (emmajoigneaux@gmail.com)

\section{Introduction}

Studying the impact of global climate change on water resources requires a combination of climate-scenario and hydrological models (Boé et al., 2009a). Water resources at the regional scale rely on particular hydrogeological contexts on which the impacts of climate change may differ extensively depending on the predominance of surface- over groundwater flows (van Roosmalen et al., 2007). With certain geomorphological settings, such as karst systems, even small changes in climatic conditions have to be studied in detail because of specific geologic hazards such as groundwaterquality vulnerability (Bonacci et al., 2006).

Climate projections based on coupled general circulation models (CGCMs) suggest a general increase in precipitation over the northern areas of Western Europe for the end of the century along with a decrease over the Mediterranean area (Christensen et al., 2007). With Europe's median latitudes marking a transition situation in terms of precipitation for most of the year, predicting the evolution of the hydrological cycle under anthropogenic forcing is beset by uncertainties (Boé et al., 2009b). Given the scale mismatch between current CGCMs and hydrological model requirements, regional downscaling of global models is necessary to study the main parameter changes of the regional hydrological cycle, particularly as regards precipitation (Habets et al., 2005; Fowler et al., 2007; Boé and Terray, 2008; Boé et al., 2009a; Tisseuil et al. 2010). The downscaling results for France forecast a decrease in summer precipitation and river discharge throughout the country at around 2050, along with an increase in winter precipitation and river discharge for southeastern France; the winter results are still very uncertain for the rest of the country (Boé et al., 2009a; Quintana Seguí et al., 2010).

Published by Copernicus Publications on behalf of the European Geosciences Union. 
Alluvial and karst hydrogeological systems are particularly affected by small changes in the hydrological components. Stream backflooding and the subsequent appearance of swallow holes can occur because of relative changes between surface and underground drainage, which are controlled by both local precipitation and spring discharge (Albéric, 2004). Consequently this type of system is sensitive to small climate variations, even at mid-latitudes.

The purpose of the present study is to assess the impact of climate variation on local hydrological cycle components by focusing on (i) an analysis of backflooding occurrences in a small catchment within the Val d'Orléans (France) over the last 40 years in order to determine how they are related to the meteorological conditions, and (ii) the prediction of backflooding frequency in the future. To study the effect of climate change on the catchment's highly variable hydrological system, we applied a statistical downscaling methodology based on the weather-type (WT) approach describing atmospheric forcing at the regional scale (Boé et al., 2006; Boé and Terray, 2008; Pagé et al., 2010). After briefly describing the study area in the Val d'Orléans, the data used for calculating past backflooding events and the methodology of the WT approach, we discuss the links between the occurrence of particular WTs and the onset of backflooding. Finally, based on different WT frequency projections, we look at future changes that could affect the hydrological components in the Val d'Orléans.

\section{The study area}

The study area is in the Val d'Orléans, in the Centre Region of France. It is a fluvial-karst system developed in the Loire floodplain and comprising three main components that are highly interactive: the groundwater in the upper part of the Beauce Limestone (Aquitanian), the Loire River and the small local rivers.

In the east of the Val d'Orléans, the Beauce Limestone is separated from the Quaternary alluvium by an impermeable sandy-clayey formation that disappears westward (Fig. 1) to bring the limestone and alluvium into contact. This enables exchanges between surface water and aquifer groundwater, and explains how the Val d'Orléans karst system is supplied mainly through leakages from the Loire (Lepiller, 2006; Joodi et al., 2010).

The Loire catchment upstream of the studied hydrological system is estimated at $36900 \mathrm{~km}^{2}$, with its main source being about $400 \mathrm{~km}$ from the Val d'Orléans. The Loire's hydrological and chemical characteristics thus differ from those of the local Val d'Orléans rivers. Tracer studies (both artificial and natural) have shown that the Loire river waters infiltrate the aquifer mainly at Jargeau and reach a number of temporary springs within a few days (3 to 4 days for the closest; Fig. 1) (Albéric and Lepiller, 1998; Lepiller, 2006). Most of these springs are located in the Loiret river which has an average flow rate of almost $1 \mathrm{~m}^{3} \mathrm{~s}^{-1}$ and whose source is the Bouillon Spring; the Loiret's actual flow rate depends mainly on the Loire river flow. Note that the two main springs of the Loiret river, the Bouillon and Abîme springs, can behave as sinks under specific hydrological and meteorological conditions. This occurs when the Loire is at a low level and when heavy local rainfall occurs in the Dhuy watershed $\left(216 \mathrm{~km}^{2}\right)$, this river being an affluent of the Loiret river (confluence $1 \mathrm{~km}$ downstream of the Bouillon spring); the surface waters of the Dhuy river backflow along the Loiret river and disappear into the Abîme and Bouillon resurgences which then act as sinkholes. Monitoring the backflooding in the Bouillon and Abîme springs over the 1997-2001 period (Albéric, 2004) showed that these events last from several hours to a maximum of several days. Intrusion of the Dhuy's turbid waters into the springs outlet is a disturbing factor for the drinking-water catchworks located near the Bouillon and Abîme springs. This occasional infiltration of surface water into the aquifer changes the physical-chemical and biological features of the groundwater and raises the fear that the drinking-water wells located a few hundred metres from the Loiret springs could become contaminated.

\section{Data and methodology}

\subsection{Meteorological and hydrological data for the 1966-2009 period}

Backflooding events were principally monitored and studied from 1997 to 2001, which is taken as a backflooding reference period since, although monitoring is still active today, only a small number of events have been recorded since 2002. This time period is not, however, long enough for a proper study of the impact of climate change on the study area, and so a reconstruction of potential past backflooding events is required.

The data necessary for reconstructing past backflooding events and studying the precipitation trend in the Val d'Orléans are the daily river flows of the Loire at Orléans and of the Dhuy, which are available in the Hydro database (http://www.hydro.eaufrance.fr/). The daily flow data for the Loire at Orléans are complete and go back to the 1960s. The Dhuy flow data, however, are incomplete with gaps from October 1971 to May 1974 and from January 1977 to the end of December 1978; these gaps can be filled with Gardenia (Thiéry, 2003), a lumped hydrological catchment model that enables one to calculate river discharges from watershed meteorological data. The most common application of the Gardenia model is for extending hydrometric data in time. Having calibrated the model on a short sequence (a few years) of river flows or levels, along with concomitant rainfall data, one uses a longer rainfall series for the model to generate a corresponding series of river flows or levels. The required data for the model are continuous daily precipitation data 


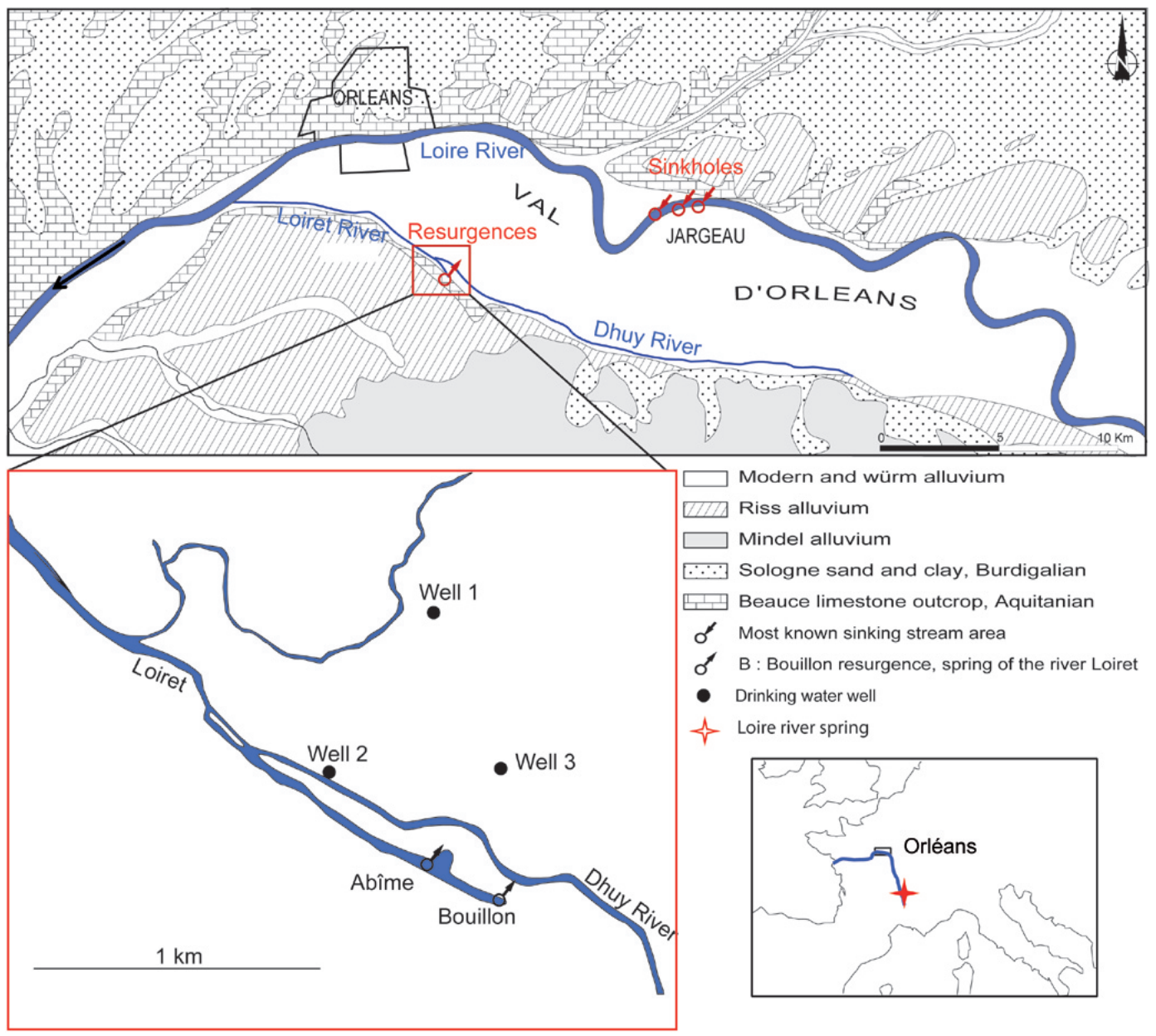

Fig. 1. Geological and hydrological setting of the study area (modified from Albéric, 2004). The Loire river, passing through the Val d'Orléans, loses water into sinkholes at Jargeau; the infiltrated surface water reaches several karst springs in the Loiret river. The Bouillon and Abîme springs are the major ones feeding the Loiret river. These resurgences can become sinkholes if the Dhuy river flows back into the Loiret river at the confluence, whereupon the infiltration of Dhuy waters into the aquifer can threaten the drinking water wells near the springs.

for the studied catchment, potential evapotranspiration (PET) data averaged over a period of ten days and available outlet discharge data. The precipitation and PET data are held by the Météo France Climate library (http://climatheque.meteo. fr/okapi/accueil/okapiWebClim/index.jsp).

\subsection{Consideration of climate change}

The trend in the number of backflooding events that will occur in the coming decades is a major question. The answer is closely related to the future regional precipitation trends.

Projections based on global climate models predict an average annual decrease in the Loire discharge for the end of the 21 st Century: the river flow will fall by $15 \%$ in winter and spring, and by possibly as much as $35 \%$ in summer and autumn (Boé et al., 2009a). On the other hand, the occurrence of low flow rates will double in 30 or 40 years. Such a trend is likely to increase the risk of backflooding in the Loiret springs. But future backflooding will also depend on the evolution of the Dhuy river flow which has never been modelled in terms of a climate change scenario.

Precipitation in Europe depends mainly on the large-scale atmospheric circulation patterns over the North Atlantic and Europe (Vautard, 1990). The daily circulation patterns can be attributed to a given state among a reduced set (typically 4 or 5) of quasi-stationary and recurrent states in order to define different weather regimes. A climate regime is thus defined by its centroid and the probability distribution function of the days around it. The regime that affects mainly the North Atlantic-Europe zone is the North Atlantic Oscillation (NAO) which represents the pressure difference between the Azores High and the Icelandic Low (Hurrell, 1995, Cassou, 2004). The NAO is divided into two phases: NAO+ also known as the Zonal Regime, and NAO-, also known as 
the Greenland High. The 1950s and 1960s saw a predominance of the NAO- phase, and the 1990s and 2000s have been marked by an intensification of the NAO+ phase (Cassou et al., 2004).

Shorthouse and Arnell (1997) have shown a close relationship between Europe's river flows and the NAO phases: their results reveal that during the winters with a frequent positive phase, the river flows are above average in the north of Europe (especially in the Nordic region), and below average in the south of Western Europe. Bouwer et al. (2006), however, showed that although the river flows in the north and south of Europe can be closely correlated with the NAO, this correlation does not really hold for the Loire flow because of its geographic position.

Weather regimes, however, represent a very large-scale approach, both spatially and temporally, in terms of our study area where the periods of backflooding are but local events lasting from a few hours to a few days. One possible answer to this problem is to consider a statistical downscaling technique based on a weather-type (WT) approach (Boé et al., 2006; Pagé et al., 2010). It is a method that has already been used for regionalising France's climate, and notably for evaluating the effect of climate change on the water resources required for different land utilisation systems (Brisson and Levrault, 2010). The WT are calculated according to the different pressure and precipitation anomalies that affect France over a year. Of the 38 WT identified for France (Pagé et al., 2010), 9 make up the December-January-February sequence (DJF0 to DJF8), 10 the March-April-May sequence (MAM0 to MAM9), 10 the June-July-August sequence (JJA0 to JJA9) and 9 the September-October-November sequence (SON0 to SON8). The method enables each day of the year to be assigned a weather type, thus making it possible to build up a daily weather database extending from 1950 to 2007.

\section{Results and discussion}

\subsection{Backflooding events during the 1997-2001 observation period}

Relating the backflooding events recorded from 1997 to 2001 to the daily Loire and Dhuy river flows (Figs. 2, 3a, b), we found that the demarcation between the Bouillon Spring's inflow (or loss) functioning and its outflow (or emergence) functioning is close to that established by Albéric (2004) based on river height. This demarcation is shown in Fig. 2 and corresponds to the following equation:

$Q_{\text {Dhuy }}=0.1+e^{0.0164 Q_{\text {Loire }}-3.1}$

where $Q_{\text {Dhuy }}$ and $Q_{\text {Loire }}$ are respectively the Dhuy river flow and the Loire river flow at Orléans. A backflooding event lasting several days is represented by several points. A backflow index $(I)$ was then established from Eq. (1):

$I=Q_{\text {Dhuy }}-e^{0.0164 Q_{\text {Loire }}-3.1}-0.1$

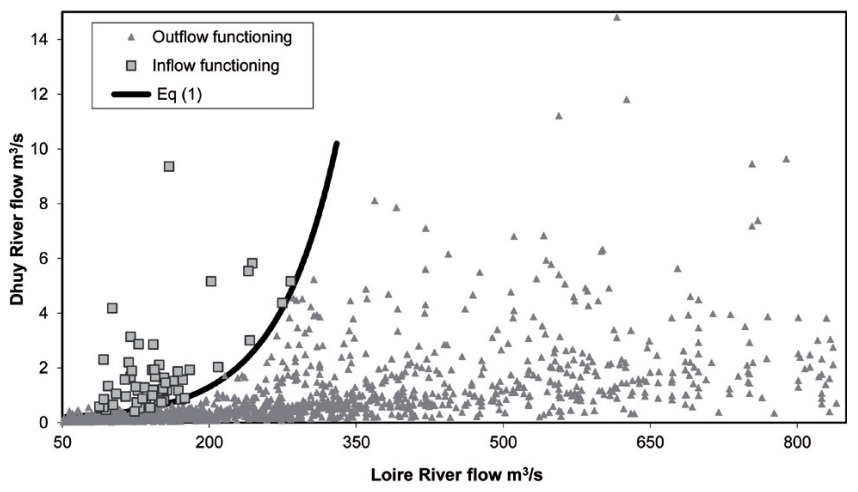

Fig. 2. Average daily Dhuy river flow versus the Loire river flow at Orléans between 1 June 1997 and 31 December 2001, with an indication of the outflow (triangles) and inflow (squares) functioning of the karstic Bouillon Spring. Note: only Loire river flows below $850 \mathrm{~m}^{3} \mathrm{~s}^{-1}$ are shown.

Thus backflooding occurs when $I>0$. From 1997 to 2001, 18 backflooding events were observed and for each one the recorded Loire and Dhuy river flows were such that $I>0$ (Fig. 3c).

\subsection{Reconstruction of river flow records for the 1966-2009 period}

The Dhuy flow time series from 1971 to 1974 and from 1977 to 1978 were completed using the Gardenia model (Thiéry, 2003) into which precipitation, PET and available Dhuy river flow data were entered. The model simulated the Dhuy flow using a hydrological system made up of three consecutive reservoirs: (i) a shallow reservoir corresponding to the uppermost few centimetres of the soil and recharged by precipitation, (ii) an intermediate reservoir corresponding to the unsaturated zone and recharged by surplus supply to the shallow reservoir - this reservoir is drained either by percolation into another reservoir and/or rapid surface seepage and runoff - and (iii) a deep reservoir recharged from the intermediate reservoir and drained by percolation or slow surface seepage and runoff. The two hydrological parameters controlling these reservoirs are WRC (i.e. Water Retention Capacity of the shallow reservoir) and RUNPER (i.e. the water level in the intermediate reservoir when rapid RUNoff and PERcolation are in equilibrium).

Several simulations were tested using different WRC and RUNPER values. However, it was found that with high WRC and RUNPER values (i.e. $>300 \mathrm{~mm}$ for WRC and $>25 \mathrm{~mm}$ for RUNPER) the simulated high Dhuy river flows were greatly underestimated, resulting in less frequent backflooding events. Conversely, with low values $(<100 \mathrm{~mm}$ for WRC and $<10 \mathrm{~mm}$ for RUNPER) the simulated high Dhuy river flows were greatly overestimated, resulting in too many backflooding events. The best values retained for this study were $205 \mathrm{~mm}$ for WRC and $15 \mathrm{~mm}$ for RUNPER, giving a 

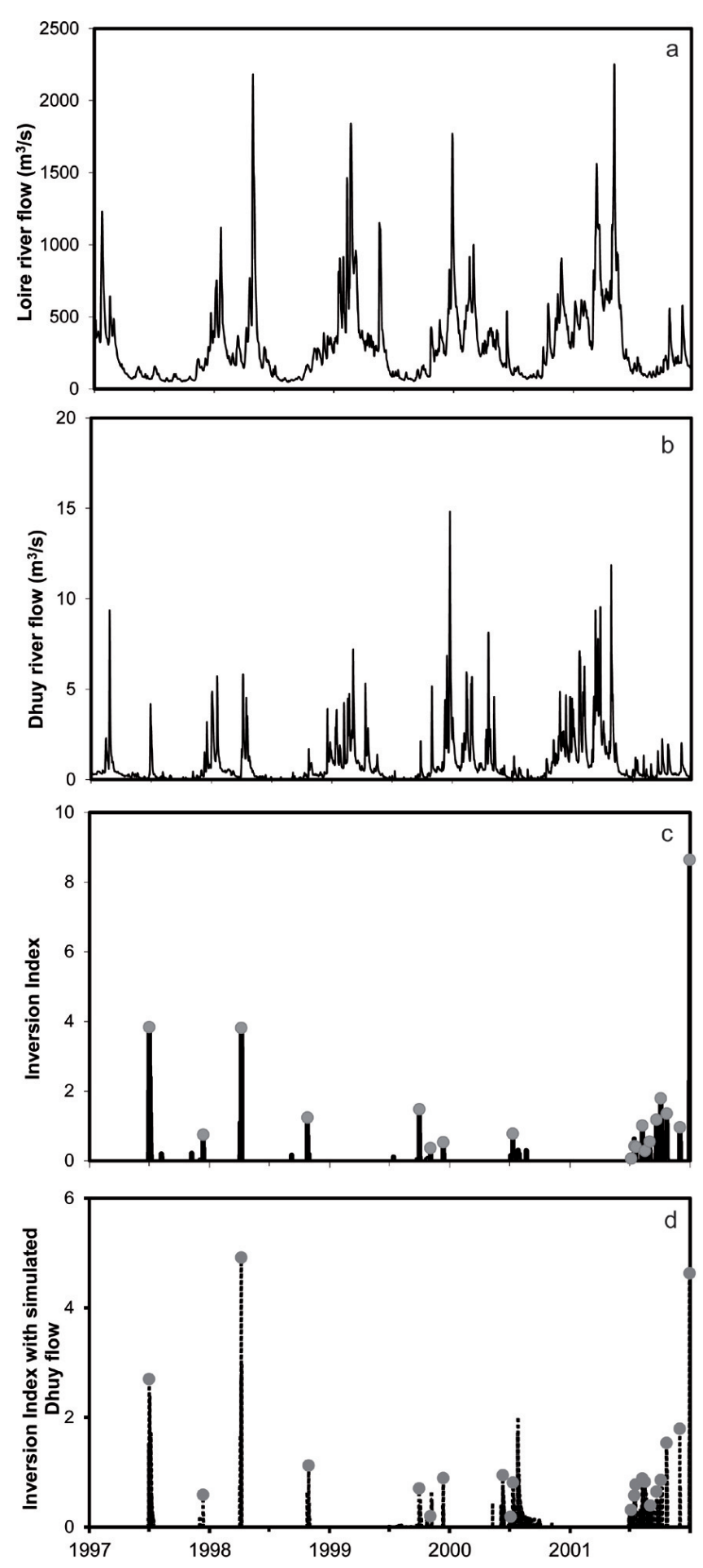

Fig. 3. Observed backflooding events and calculated backflow indices for 1997 to 2001. From the top down: Loire river flow (a), Dhuy river flow (b), backflow index calculated with the actual Dhuy river flows and the backflooding observations (grey circles) (c), backflow index calculated with the Gardenia-calculated Dhuy river flows and the backflooding observations (grey circles) (d). simulation that provided an average amount of backflooding events without any priority to very high or very low flows.

The best simulations carried out for the entire 1966-2009 period gave a correlation coefficient of 0.884 and a mean quadratic deviation of $0.59 \mathrm{~m}^{3} \mathrm{~s}^{-1}$ between the simulated and actual flows for the periods of known Dhuy river flow. We also calculated the Nash-Sutcliffe Efficiency (NSE) for a better idea of the simulation performance. This gave about 0.78 for the overall period because the model trends to underestimate high flows $\left(>1 \mathrm{~m}^{3} \mathrm{~s}^{-1}\right)$ and slightly overestimate low flows $\left(<0.5 \mathrm{~m}^{3} \mathrm{~s}^{-1}\right)$. Nevertheless, it was more important to have a good overall simulation for the present study than to prioritize either high flow peaks or low flow periods.

The backflow indices calculated from the simulated river flows, like those calculated from the actual river flows, are in agreement with the observations made in the field during the 1997-2001 reference period (Fig. 3c, d). It was noted, however, that the duration of the different backflooding events deduced from the simulated river flows are much longer than those deduced from the actual river flows during the low water periods of 2000 and 2001. This difference is explained by the positive bias (possibly due to evapotranspiration) between the simulated and actual flows of $<0.5 \mathrm{~m}^{3} \mathrm{~s}^{-1}$ at the low water period shown by all the simulated records; the result is an overestimation of the simulated flows compared to the actual flows. The simulated river flows being higher than the actual ones during the June to September period means that the simulated backflooding events are longer.

\subsection{Simulation of the backflooding events for the 1966-2009 period}

One hundred and twenty three backflooding events (i.e. $I>0$ ) were calculated for the 1966 to 2009 period using the actual Dhuy and Loire river flows. With the Gardeniasimulated Dhuy river flows for the same period, $73 \%$ (or 90) of the backflooding events satisfied the condition $I>0$. Of the 33 non-simulated backflooding events, 18 lasted for less than a day: these very short events are difficult for Gardenia to distinguish because the model has a tendency to clip the high river flows. It is thus possible that some of the non-simulated backflooding events, which doubtless existed given the actual Dhuy and Loire river flows, were not correctly simulated because of their brevity. If one then takes into consideration the slightly negative $(I)$ values $(I=-0.3-0)$, one now finds that Gardenia in fact simulated $93 \%$ of the backflooding events calculated from the measured river flows. The underestimation (due to the choice of the values of WRC and RUNPER) of the Dhuy river flows greater than $1 \mathrm{~m}^{3} \mathrm{~s}^{-1}$ would also explain why all the observed backflooding events were not recognised from the Gardenia-simulated river flows.

Figure 4 shows the backflooding occurrences calculated from the measured river flows (1966-2009) completed by simulated river flows for the period between 1971 and 1979. 


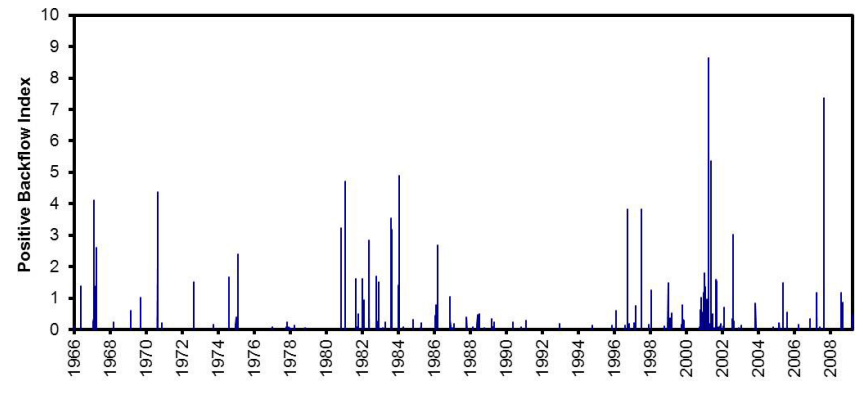

Fig. 4. Backflooding events between 1966 and 2009.

A total of 126 backflooding events was calculated with two particularly favourable periods for their occurrence being identified: one between 1981 and 1989, and the other between 1997 and 2003. Before the 1980s, there would have been a few fairly localised backflooding occurrences. It is interesting to note that the period of high backflooding frequency occurs when the Dhuy river flow is high on the pluriannual scale (not shown). This clearly indicates that although the appearance of backflooding is, on the daily scale, linked to the local river flows, its frequency is associated with the rainfall sequences of the order of several years.

\subsection{Relationship between backflooding events and weather types (WT)}

\subsubsection{Weather types and Dhuy flow}

The daily record of weather types and the daily Dhuy river flows were combined for the 1966-2007 period (Fig. 5) and several methods were tested to evaluate the best relationship between the daily WT and the presence of backflooding events. In one of these methods, each daily WT was related to a weighted moving average of the Dhuy flow over the three days following the appearance of the WT - this was motivated by the fact that heavy rainfall related to a specific WT will influence the Dhuy flow for up to three days following the event. Nevertheless, when the daily WT was related to the average Dhuy flow merely over one day following the event, we recorded similar results as for the average Dhuy flow over the three day period following the event. Consequently, we calculated the variability of the Dhuy river flow using the ratio $\left(R_{\mathrm{WT}}\right)$ of the average Dhuy flow at day +1 for each WT at day 0 over the average Dhuy flow for each season; this is given by the relationship (Fig. 5):

$R_{\mathrm{WT}}=\frac{\sum_{\mathrm{WT}} Q_{\text {Dhuy }} / n_{\mathrm{WT}}}{\sum_{\text {season }} Q_{\text {Dhuy }} / n_{\text {season }}}$

with $n_{\mathrm{WT}}$ the number of days that the WT appeared between 1966 and 2007 and $n_{\text {season }}$ the total number of days in the considered season between 1966 and 2007.

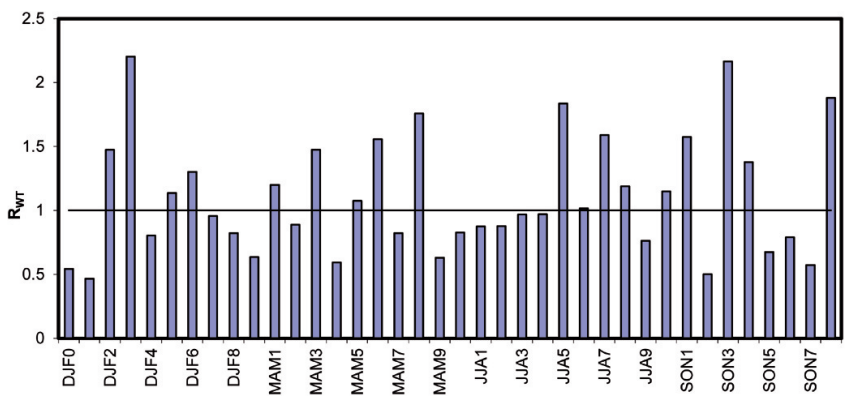

Fig. 5. Variability of the Dhuy river flow represented by the $R_{\mathrm{WT}}$ ratio for each weather type compared to the average seasonal flow. Note: $R_{\mathrm{WT}}=1$ corresponds to the average seasonal Dhuy river flow for the considered season.

The WT are differentiated by a precise trend in the Dhuy river flow compared to its seasonal average. The value of the ratio ( 1 being the seasonal average of the river flow) enables one to distinguish the WTs associated with the Dhuy high river flows $\left(R_{\mathrm{WT}}>1\right)$ and those associated with the Dhuy low river flows $\left(R_{\mathrm{WT}}<1\right)$ (Fig. 5).

The impact of each WT can be also given by the variability of its precipitation in relation to the average seasonal precipitation (Table 1). Most WTs can be termed as "wet" if they give rise to more precipitation than the seasonal average, or "dry" if they give rise to less precipitation. These data are consistent with the results shown in Fig. 5.

\subsubsection{Weather types and backflooding events}

We studied the occurrences of backflooding in relation to the WT, and noted that they are potentially higher with sudden increases in the Dhuy river flow compared to the Loire river flow. The combined trends of the Loire and Dhuy river flows, the precipitation in the study area, the backflooding occurrences and the WTs were analysed in detail for the period between 1966 and 2007. Two examples taken from the backflooding observation period (1997-2001) illustrate these trends: one during a low-water period when the level of the Loire was stable (Fig. 6a) and one during a winter period when the level of the Loire was fluctuating (Fig. 6b). Figure 6a shows the link between the appearance of backflooding events, local precipitation and the trend of the Dhuy and Loire river flows from June to August 2000. Certain WTs during this low flow period of the Loire gave rise to high precipitation in the study area and thus increased the Dhuy river flow. Backflooding was possible because the Loire river flow varied between 80 and $155 \mathrm{~m}^{3} \mathrm{~s}^{-1}$. The succession of WTs JJA8, JJA7 and JJA5 during the summer of 2000 was at the origin of these backflooding events: it is the sum of the rainy days that gives rise to backflooding. This combination of WTs was responsible for seven summer backflooding events during the observation period. During the winter period (Fig. 6b), the succession of several days associated with a 
Table 1. Precipitation variability of each WT according to the seasonal precipitation rates.

\begin{tabular}{lrlrrr}
\hline "Dry" WTs & $\begin{array}{r}\text { Variability } \\
\text { of precipitation }\end{array}$ & "Wet" WTs & $\begin{array}{r}\text { Variability } \\
\text { of precipitation }\end{array}$ & Other WTs & $\begin{array}{r}\text { Variability } \\
\text { of precipitation }\end{array}$ \\
\hline DJF0 & $-62 \%$ & DJF2 & $39 \%$ & DJF8 & $8 \%$ \\
DJF1 & $-89 \%$ & DJF3 & $177 \%$ & DJF5 & $9 \%$ \\
DJF4 & $-32 \%$ & DJF6 & $104 \%$ & JJA2 & $8 \%$ \\
DJF7 & $-54 \%$ & MAM1 & $55 \%$ & JJA4 & $1 \%$ \\
MAM0 & $-60 \%$ & MAM3 & $41 \%$ & JJA6 & $8 \%$ \\
MAM2 & $-11 \%$ & MAM5 & $32 \%$ & SON0 & $-5 \%$ \\
MAM4 & $-91 \%$ & MAM6 & $100 \%$ & \\
MAM7 & $-17 \%$ & MAM8 & $120 \%$ & \\
MAM9 & $-54 \%$ & JJA5 & $189 \%$ & \\
JJA0 & $-40 \%$ & JJA7 & $183 \%$ & \\
JJA1 & $-80 \%$ & JJA8 & $190 \%$ & \\
JJA3 & $-66 \%$ & SON1 & $41 \%$ & \\
JJA9 & $-63 \%$ & SON3 & $144 \%$ & & \\
SON2 & $-45 \%$ & SON4 & $65 \%$ & & \\
SON6 & $-50 \%$ & SON5 & $22 \%$ & & \\
SON7 & $-85 \%$ & SON8 & $154 \%$ & & \\
\hline
\end{tabular}
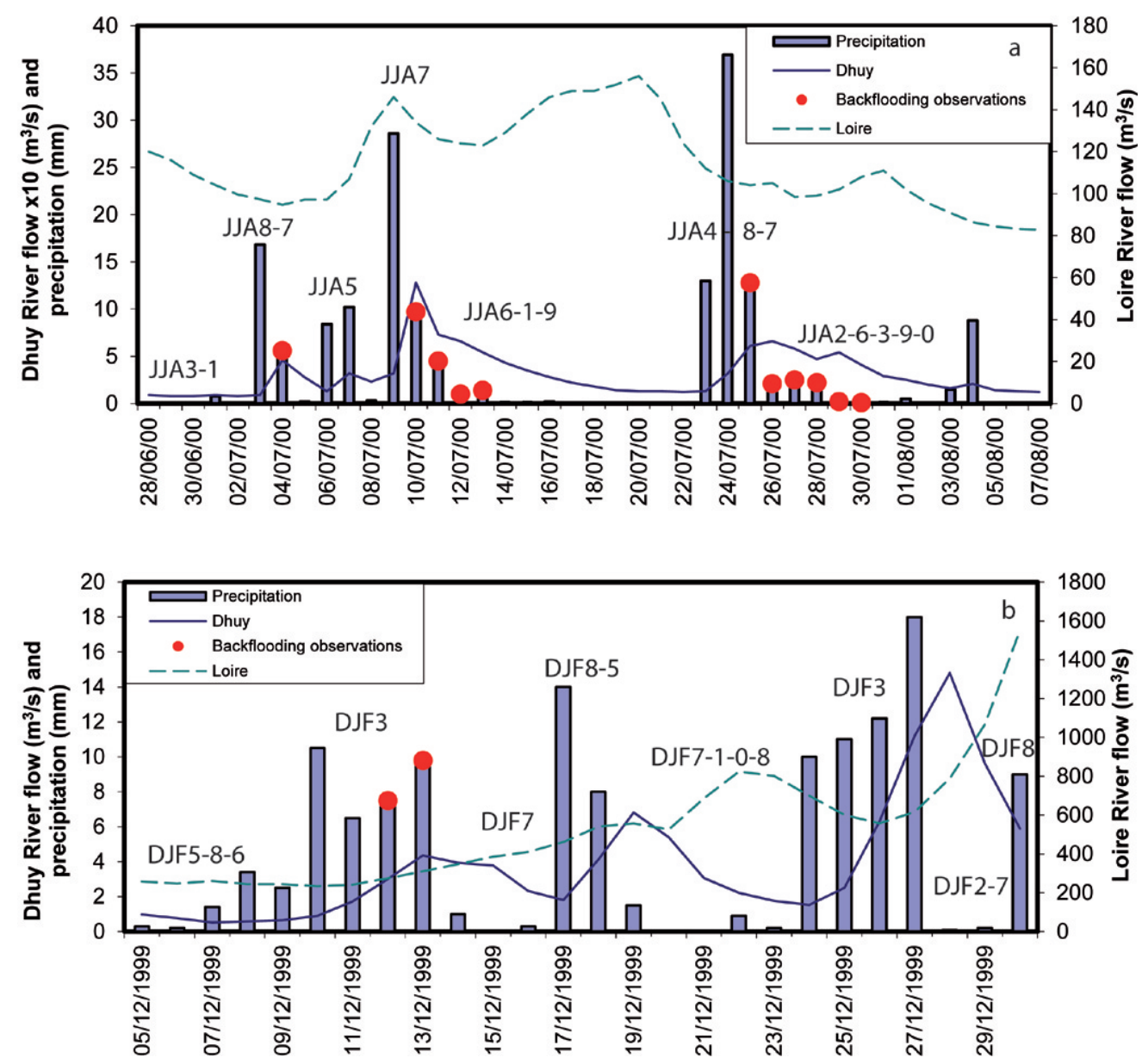

Fig. 6. Precipitations, Loire river flow, Dhuy river flow, backflooding observations and associated WT during a period of Loire stability (a) and a period of Loire high river flow (b). 


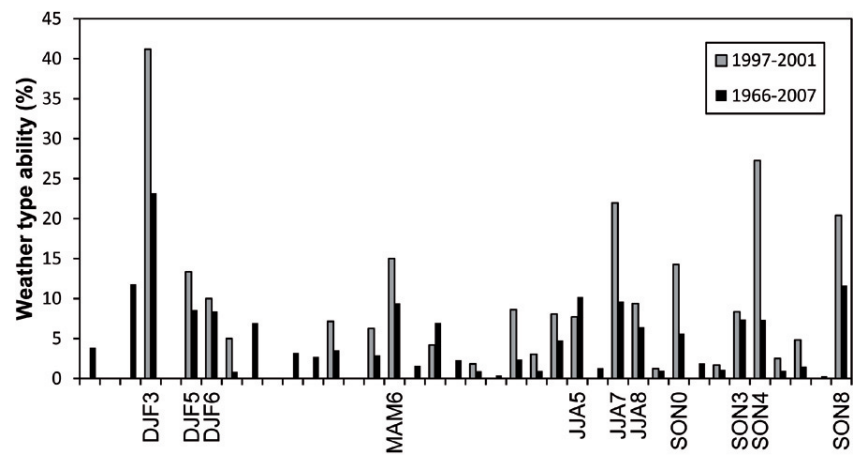

Fig. 7. Ability of the WTs to trigger backflooding, calculated over two periods: 1997-2001 and 1966-2007.

same WT, i.e. DJF3, triggered backflooding due to increased precipitation over the Loiret; this WT was responsible for two of the three December backflooding events that occurred between 1997 and 2001. DJF3 also reappeared several times during this winter period but without triggering any backflooding because the Loire river flow gradually increased making any backflooding impossible; above $350 \mathrm{~m}^{3} \mathrm{~s}^{-1}$ the Loire river flow is too high to enable backflooding. Other WTs brought high precipitation during the considered winter period (Fig. 6b); for example, DJF8 was twice associated in this example with a high precipitation level, but did not trigger any backflooding. Nevertheless, when one compares the average Dhuy river flow under DJF8 with the seasonal average (i.e. the $R_{\mathrm{WT}}$ ratio; Fig. 5) one notes that DJF8 tends for a lower river flow than the seasonal average. Thus even though DJF8, when averaged over 40 years, is representative of a low Dhuy river flow compared to the seasonal average, it can nevertheless, on any particular day, contribute to an abrupt rise in the river level.

Studying the complete 1966-2007 sequence allowed us to determine for each WT a number of days of appearance that could lead to backflooding. However, they are values that need to be weighted in relation to the seasonal occurrence of each WT. The result of the weighting is the aptitude of a WT to cause backflooding, which is defined as follows:

$\mathrm{Apt}_{\mathrm{WT}}=\frac{m^{\mathrm{WT}}}{p^{\mathrm{WT}}}$

where $m^{\mathrm{WT}}$ is the number of days that the WT triggers a backflooding and $p^{\mathrm{WT}}$ the occurrence of the WT in the season during the considered period. Only days when the Loire river flow was $<350 \mathrm{~m}^{3} \mathrm{~s}^{-1}$ were used for this calculation for the simple reason that backflooding events cannot occur when the Loire flow is $>350 \mathrm{~m}^{3} \mathrm{~s}^{-1}$. Figure 7 shows the aptitude of the WTs to generate backflooding over two periods: 1966-2007 (overall period) and 1997-2001 (period of backflooding observation). One obtains basically the same results for the two periods: it is the same WTs that have a high ability to trigger backflooding. Termed backflow-triggering

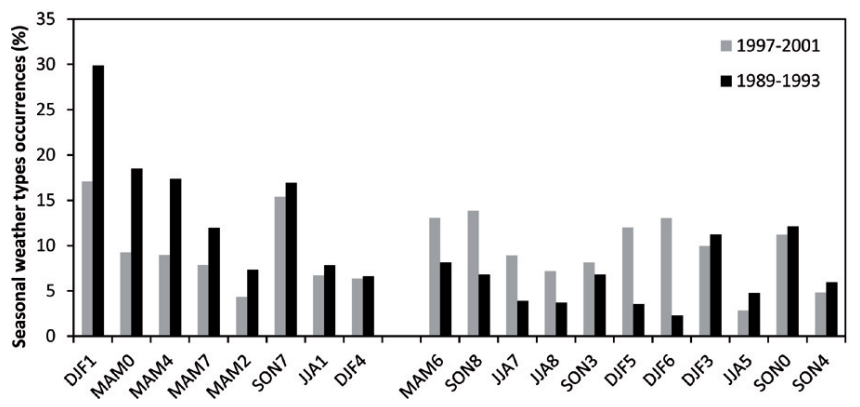

Fig. 8. Comparison of WT occurrences for the periods with (19972001) and without (1989-1993) backflooding.

WTs, the distribution of WTs capable of triggering backflooding is as follows: three winter WTs (DJF3, DJF5 and DJF6), one spring WT (MAM6), three summer WTs (JJA5, JJA7, JJA8) and four autumn WTs (SON0, SON3, SON4 and SON8).

The 1997-2001 observation period was a time of many backflooding events compared to the preceding and following periods. In order to confirm the preceding result (Fig. 7) and better understand the backflooding phenomenon on a multi-annual scale, we compared the occurrences of backflow-triggering WTs and non-triggering WTs over the observation period with those over the 1989-1993 period with no backflooding events (Fig. 8). Seven triggering WTs (MAM6, DJF5, DJF6, JJA7, JJA8, SON3, and SON8) appeared more frequently over the four years of the observation period than during the 1989-1993 period, whereas the non-triggering WTs (i.e. those give rise to low Dhuy river flows, such as DJF1, MAM0, MAM2, MAM4, MAM7, SON7 and JJA1) appeared more frequently during the 19891993 period with no backflooding; here the higher frequency of non-triggering WTs would in part explain the low level of the Dhuy during this period. This comparison between the periods with backflooding and no backflooding allowed us to confirm the major role played by certain WTs, i.e. the backflow-triggering and non-triggering WTs.

All the triggering WTs defined above are well related to a $R_{\text {WT }}>1$, i.e. to Dhuy flows higher than the seasonal average (Fig. 5). However, only 11 of the 17 "wet" WTs (Fig. 5) are considered to be backflow-triggering WTs because a major role is also played by the hydrological regime of the Loire river.

\subsubsection{Weather types and Loire flow}

Linking the Dhuy river flows to daily weather types is easy because the Dhuy is a local river in a small catchment and reacts instantaneously to precipitation. This is not the case for the Loire river for the scale is not the same; the catchment dimensions make it very difficult to link the Loire river flow to specific weather type occurrences. The Loire river takes several days, even weeks, to integrate the impact of a weather 

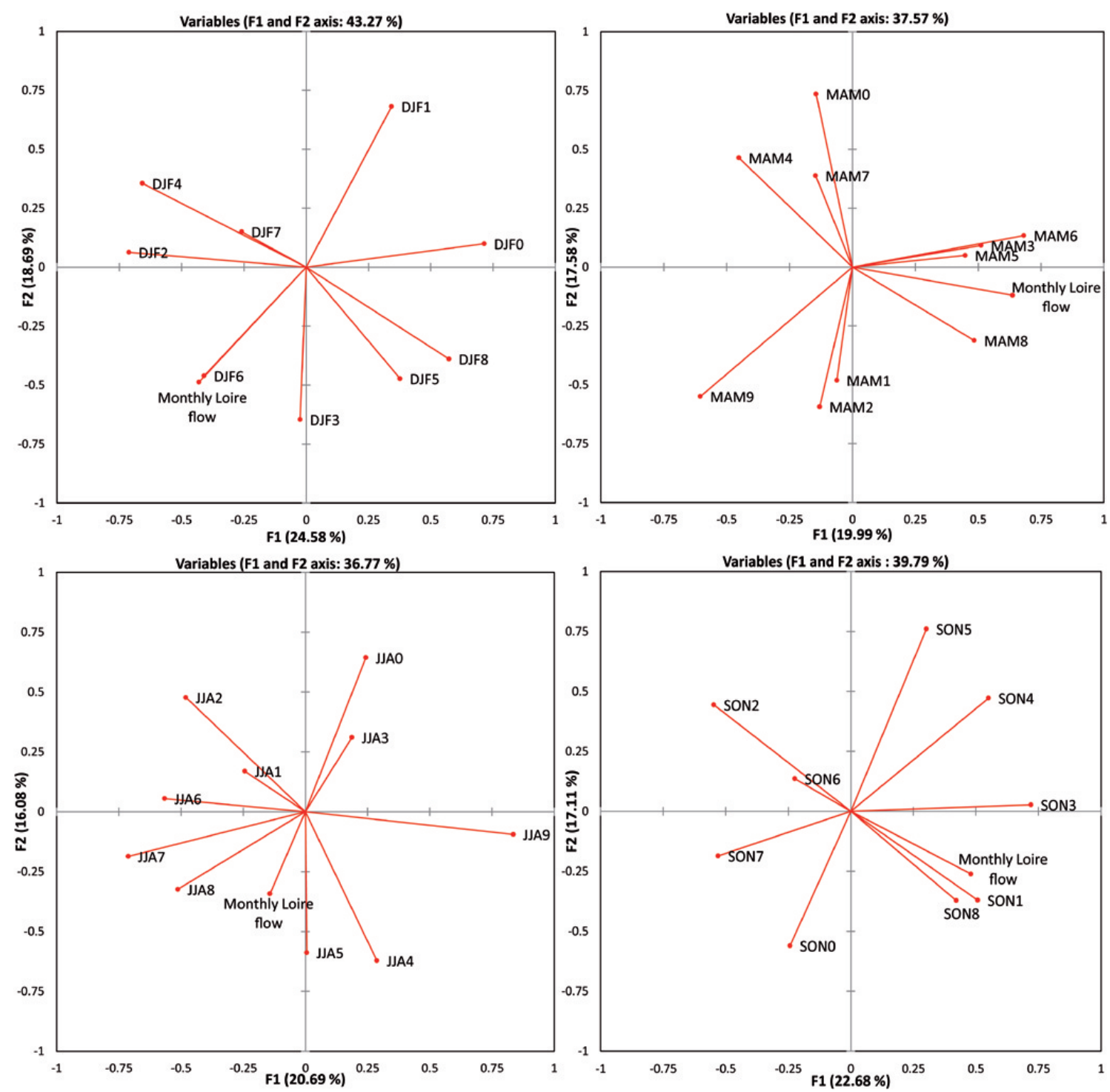

Fig. 9. Relationship between monthly Loire river flows and the occurrence of WTs with the PCA method.

type, and so the river flow reflects the sequence of several weather types over a certain period. Accordingly, we tried linking monthly Loire river flows to the occurrences of WTs using a Principal Component Analysis (PCA) and correlation matrix for each season. The results show that only a few WTs have an impact on the monthly Loire river flow, and that this impact is very slight compared to the WT impacts on the Dhuy river flow; thus DJF2, DJF3, DJF6, MAM3, MAM6 and SON3 are linked to monthly high Loire flow, and DJF0, DJF1, MAM0, MAM4 and SON 2 are linked to monthly low Loire flow (Fig. 9). Then again, among these WTs, only DJF3, MAM6 and SON3 can be considered as triggering WTs and only DJF1, MAM0 and MAM4 as nontriggering WTs. These results clearly show that linking the Loire river flow with WTs is difficult to achieve.

\subsection{Projected trend in occurrences of backflooding as a function of WTs}

Simulations of the WT frequency trend were carried out for several downscaled global climate scenarios (Pagé et al., 2008). The results of five of the downscaled simulations were used in this study. The data enabled us to evaluate the trend in backflooding occurrences which we have already discussed as a function of weather type.

\subsubsection{ARPEGE simulation}

The ARPEGE simulation originates from the CNRM (French National Centre for Meteorological Research) and is currently used for climate impact studies (e.g. Boé et al., 2006, 2009a; Boé and Terray, 2008; Quintana Seguí et al., 2010; 


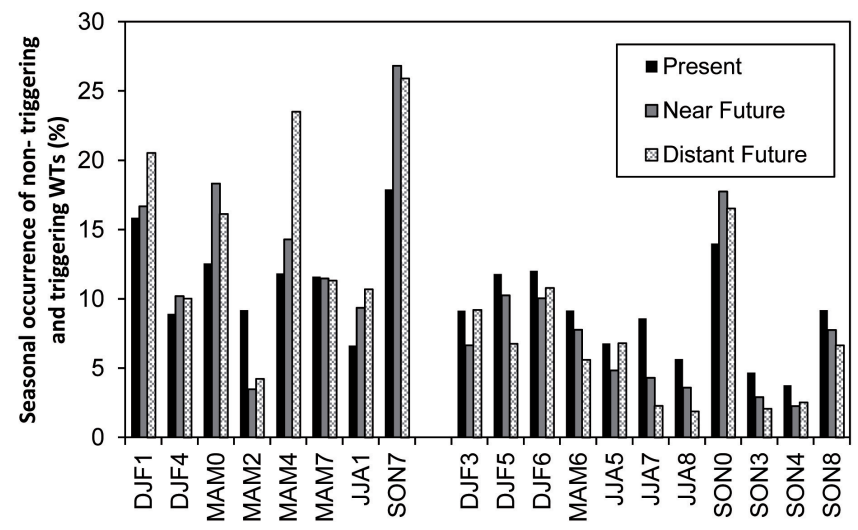

Fig. 10. Evolution of the seasonal occurrence of non-triggering and triggering-WTs under the ARPEGE scenario.
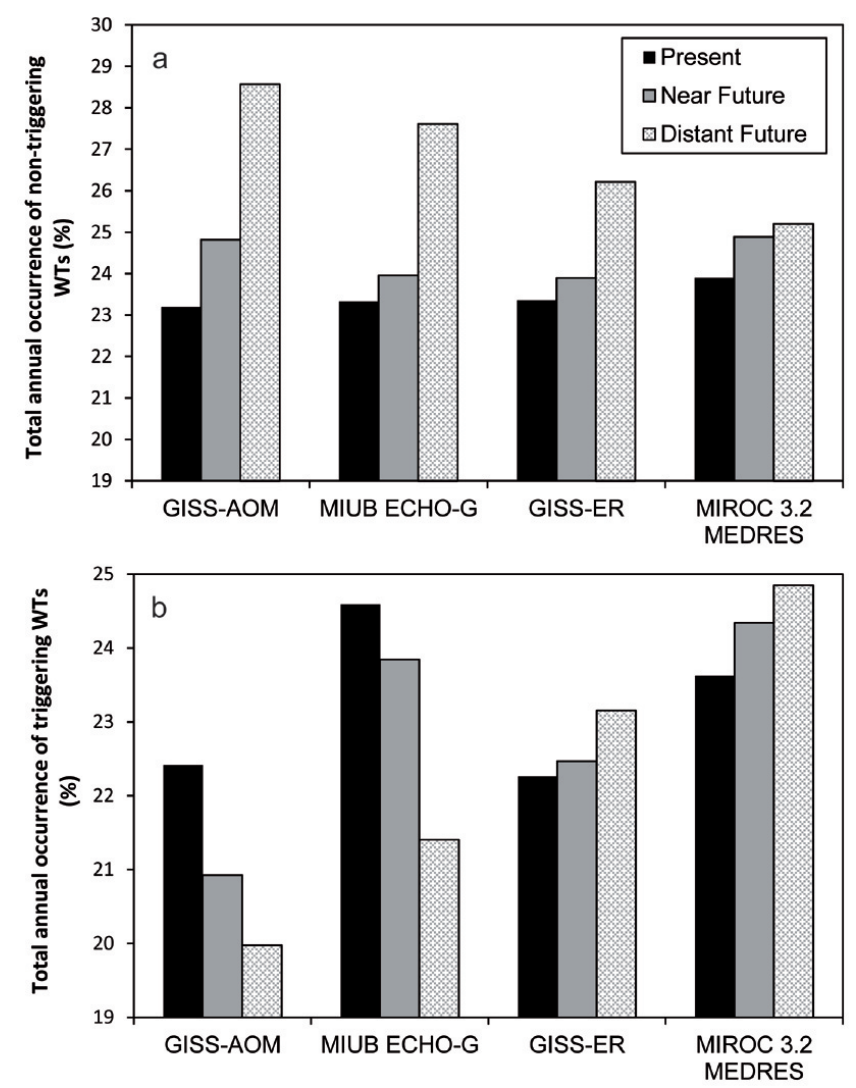

Fig. 11. Total annual occurrence (\%) of backflow non-triggering WTs (a) and triggering WTs (b) between the Present and the Near and Distant futures according to the four simulations.

Planton et al., 2008). Three time periods were studied for predicting the WT trends: 1961-2000 (Present), 20462065 (Near future) and 2081-2100 (Distant future). Figure 10 shows the seasonal occurrence of triggering and non-triggering WTs for the three time periods described above. According to this scenario, the frequency of six non- triggering WTs will increase in the Near future, that of one will remain constant and that of only one will decrease; for the triggering WTs. The frequency of ten will decrease and that of only one will increase. These results change when considering the Distant future in relation to the Present - the frequency of eight triggering WTs will decrease, that of two will stay constant and that of only one will increase. Consequently, the occurrence of backflow events in the Near future and Distant future will, according to this climate scenario, tend to decrease in frequency.

\subsubsection{Other simulations}

Although the ARPEGE climate scenario provides satisfactory results, the use of other climate simulations is needed to illustrate the variability and uncertainties of different models on the same study area. The four simulations used in this section are GISS-AOM, GISS-ER, MIROC3.2-MEDRES and MIUB-ECHO-G, all of which are part of IPCC's SRES A1B scenario (Randall et al., 2007). These simulations were selected because each is representative of a specific future climatic state: MIROC 3.2 MEDRES represents a future climate that is much warmer and wetter than at present. GISS ER is again a feature of a warmer and wetter future climate, whereas GISS AOM represents a warmer and drier future climate, and MIUB ECHO G a much warmer and drier future climate.

The eleven backflow triggering WTs and the eight nontriggering WTs were considered as two distinct groups for the Present/Near future/Distant future comparisons - their total annual occurrences are shown in Fig. 11. All four simulations indicated that the non-triggering WTs will increase in frequency in the Near and Distant future (Fig. 11a) and two simulations (GISS-ER, MIROC3.2-MEDRES) also indicated a frequency increase for the backflow-triggering WTs. Conversely, the two other simulations (GISS-AOM and MIUB-ECHO-G) showed a decreasing frequency for backflow-triggering WTs in the future (Fig. 11b).

There is thus a well-marked trend for the non-triggering WTs towards an increase in both the Near and Distant future, and this with each simulation. For the backflow-triggering WTs, however, the GISS-AOM and MIUB-ECHO-G simulations predict a decrease in their frequency, whereas the GISS-ER and MIROC3.2-MEDRES simulations tend to indicate an increase. The different results obtained from these models reflect each model's characteristics; i.e. horizontal resolution, number of vertical levels, physical parameterisation, numerical methods, intrinsic internal climate variability, etc. (Randall et al., 2007). The GISS-ER and MIROC 3.2 MEDRES simulations, which both indicate a wetter climate for the future, show the same predicted evolution (increased frequency of backflow-triggering WTs) whereas the GISS-AOM and MIUB-ECHO-G simulations, which indicate a drier climate for the future, show a decrease in frequency of backflow-triggering WTs. Thus the GISS-ER and 
MIROC3.2-MEDRES models agree about a lessening of the backflooding risk (increase of non-triggering WTs and decrease of backflow-triggering WTs) like ARPEGE and the other two models tend to indicate an increase of the backflooding risk (increase in both the non-triggering and the backflow-triggering WTs, and thus fewer intermediate WTs to compensate the increase).

If one considers that backflooding represents an extreme event in the Val d'Orléans (sudden increase in precipitation), other more specialised studies on the future frequency of extreme events help us complete the results obtained using the WT method. The models agree in predicting an increase in the number of days of drought in summer and of intense precipitation in winter (Déqué, 2007; Moisselin and Dubuisson, 2006). Planton et al. (2008) also explain that the change in the occurrence of weather regimes in the future will favour intense precipitation events in excess of $10 \mathrm{~mm}$ in winter, especially in the northern half of France. But the models do not succeed in evaluating the trend of very intense precipitations in the southeast of France (including the Cevennes episodes that partly feed the Loire) because they are not capable of reproducing small-scale events in the current climate conditions. The ARPEGE and LMDZ models used for the IMFREX project (Projet GICC-IMFREX, 2005) simulated the trend of the number of days with more than $10 \mathrm{~mm}$ precipitation in France for 2070-2099. For the Val d'Orléans, the two models predict a decrease in the number of days in summer and a slight increase (for LMDZ) in winter. In autumn and spring, the number of days of intense precipitation will not change for the study area. In predicting that the number of days of intense rain will decrease in summer, these simulations indicate a lower risk of backflooding.

\section{Conclusions}

It has been shown that karst systems can be very sensitive to climate change. The switch from an outflow (or emergence) function to an inflow (or loss) function can lead to a potential quality degradation of the groundwater resource. The occurrences of this occasional event were reconstructed for the last 40 years based on river flow data. Periods of several years with a large number of backflooding events and periods with almost no backflooding events succeeded one another and appear to be directly related to the multi-annual variations of the river flow.

For the present study a correlation was made between local precipitation variations and the large-scale atmospheric circulations that affect Europe. Statistical downscaling of the weather regimes has made it possible to determine the weather types that condition the onset of backflooding; it would appear that certain weather types control the frequency of backflooding events over time. The method of linking WT and backflooding has enabled us, based on an ARPEGE climate projection, to propose trend scenarios for the occurrence of backflooding and to project a decrease of the backflow-triggering WT and an increase of the nontriggering WT; the overall result is a potential decrease of backflow events in the future. However, one must consider the various uncertainties that can affect this method; i.e. uncertainties linked to future emission scenarios of greenhouse gases, to the different simulations used, to knowledge of the physical processes, to the downscaling and to the differences between downscaling methods, and above all to the intrinsic atmospheric variability of weather types. As long as it is possible to correctly assess the impact of each WT on a specific hydrological site, the deployed method could be applied to other climate change impact studies.

Acknowledgements. The authors are grateful to the DIRENCentre for their role in making the river flow data available. We acknowledge the Région Centre for co-funding this $\mathrm{PhD}$, and also acknowledge the Program for Climate Model Diagnosis and Intercomparison (PCMDI) and the WCRP's Working Group on Coupled Modelling (WGCM) for the WCRP CMIP3 multi-model dataset. Alexis Gutierrez, Stéphane Binet and Florence Habets are thanked for constructive discussions.

Edited by: E. Morin

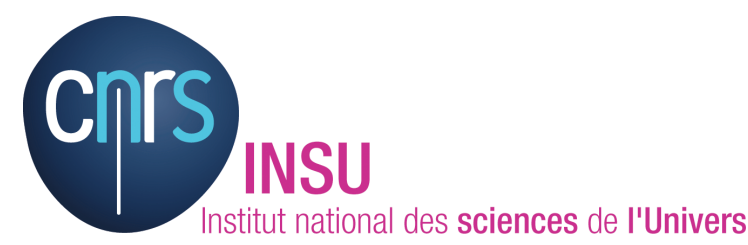

The publication of this article is financed by CNRS-INSU.

\section{References}

Albéric, P.: River backflooding into a karst resurgence (Loiret, France), J. Hydrol., 286, 194-202, 2004.

Albéric, P. and Lepiller, M.: Oxidation of organic matter in a karstic hydrologic unit supplied through stream sinks (Loiret, France), Water Res., 32(7), 2051-2064, 1998.

Boé, J. and Terray, L.: A weather type approach to analysing winter precipitation in France: 20th century trends and role of anthropogenic forcing, J. Climate, 21, 3118-3133, 2008.

Boé, J., Terray, L., Habets, F., and Martin, E.: A simple statistical-dynamical downscaling scheme based on weather types and conditional resampling, J. Geophys. Res., 111, D23106, doi:10.1029/2005JD006889, 2006.

Boé, J., Terray L., Martin E., and Habets, F.: Projected changes in components of the hydrological cycle in French river basins during the 21 st century, Water Resour. Res., 45, W08426, doi:10.1029/2008WR007437, 2009a.

Boé, J., Terray, L., Cassou, C., and Najac, J.: Uncertainties in European summer precipitation changes: role of large scale circulation, Clim. Dynam., 33, 265-276, 2009b.

Bonacci, O., Ljubenkov, I., and Roje-Bonacci, T.: Karst flash floods: an example from the Dinaric karst (Croatia), Nat. Haz- 
ards Earth Syst. Sci., 6, 195-203, doi:10.5194/nhess-6-1952006, 2006.

Bouwer, L. M., Vermaat, J. E., and Aerts, J. C. J. H.: Winter atmospheric circulation and river discharge in northwest Europe, Geophys. Res. Lett., 33, L06403, doi:10.1029/2005GL025548, 2006.

Brisson, N. and Levrault, F.: Changement climatique, agriculture et forêt en France : simulations d'impacts sur les principales espèces. Le Livre Vert du projet CLIMATOR (2007-2010), ADEME, 336 pp. 2010.

Cassou, C.: Du changement climatique aux régimes de temps: l'oscillation nord atlantique, La Météorologie, 45, 21-32, 2004.

Cassou, C., Terray, L., Hurrel, J. W., and Deser, C.: North Atlantic Winter Climate Regimes: Spatial Asymmetry, Stationarity with Time, and Oceanic Forcing, J. Climate, 17, 1055-1068, 2004.

Christensen, J. H., Hewitson, B., Busuioc, A., Chen, A., Gao, X., Held, I., Jones, R., Kolli, R. K., Kwon W.-T., Laprise, R., Magaña Rueda, V., Mearns, L., Menéndez, C. G., Räisänen, J., Rinke, A., Sarr, A., and Whetton, P.: Regional Climate Projections, edited by: Solomon, S., Qin, D., Manning, M., Chen, Z., Marquis, M., Averyt, K. B., Tignor, M., and Miller, H. L., Climate Change 2007: The Physical Science Basis, Contribution of Working Group I to the Fourth Assessment Report of the Intergovernmental Panel on Climate Change, Cambridge University Press, Cambridge, United Kingdom and New York, NY, USA, 2007.

Déqué, M.: Frequency of precipitation and temperature extremes over France in an anthropogenic scenario: Model results and statistical correction according to observed values, Global Planet. Change, 57, 16-26, 2007.

Fowler, H. J., Blenkinsop, S., and Tebaldi, C.: Linking climate change modelling to impact studies: recent advances in downscaling techniques for hydrological modeling, Int. J. Climatol., 27, 1547-1578, 2007.

Habets, F., Ducrocq, V., andn Noilhan, J.: Prévisions hydrologiques et échelles spatiales : l'exemple des modèles opérationnels de Météo-France, C. R. Geosci., 337, 181-192, doi:10.1016/j.crte.2004.08.009, 2005.

Hurrell, J. W.: Decadal trends in the North Atlantic Oscillation: regional temperatures and precipitation, Science, New Series, 269, No. 5224, 676-679, 1995.

Joodi, A. S., Sizaret, S., Binet, S., Bruand, A., Alberic, P., and Lepiller, M.: Development of a Darcy - Brinkman model to simulate water flow and tracer transport in a heterogeneous karstic aquifer (Val d'Orléans, France), Hydrogeol. J., 18, 295-309, 2010.

Lepiller, M.: Val d'Orléans, edited by: Roux, J.-C., Aquifères et eaux souterraines en France, Editions Jean-Claude Roux, BRGM Volume I, 200-214, 2006

Moisselin, J. M. and Dubuisson, B.: Evolution des valeurs extrêmes de température et de précipitations au cours du XXème siècle en France, La Météorologie, 54, 33-42, 2006.
Pagé, C., Terray, L., and Boé, J.: Projections climatiques à échelle fine sur la France pour le 21ème siècle: les scénarii SCRATCH08, Technical Report TR/CMGC/08/64, Centre Européen de Recherche et de Formation Avancée en Calcul Scientifique (CERFACS), 2008.

Pagé, C., Terray, L., and Boé, J.: dsclim: A software package to downscale climate scenarios at regional scale using a weather-typing based statistical methodology, Technical Report TR/CMGC/09/21, Centre Européen de Recherche et de Formation Avancée en Calcul Scientifique (CERFACS), available at: http://www.cerfacs.fr/ $\sim$ page/dsclim/dsclim_doc-latest. pdf, 2010.

Planton, S., Déqué, M., Chauvin, F., and Terray, L.: Expected impacts of climate change on extreme climate events, C. R. Geosci., 340, 564-574, 2008.

Projet GICC-IMFREX: Impact des changements anthropiques sur la fréquence des phénomènes extrêmes de vent, de température et de précipitations, Rapport final http://imfrex.mediasfrance.org/ web/resultats/diagmod/index, 2005.

Quintana Seguí, P., Ribes, A., Martin, E., Habets, F., and Boé, J.: Comparison of three downscaling methods in simulating the impact of climate change on the hydrology of Mediterranean basins, J. Hydrol., 383, 111-124, 2010.

Randall, D. A., Wood, R. A., Bony, S., Colman, R., Fichefet, T., Fyfe, J., Kattsov, V., Pitman, A., Shukla, J., Srinivasan, J., Stouffer, R. J., Sumi, A., and Taylor, K. E.: Climate Models and Their Evaluation, in: Climate Change 2007: The Physical Science Basis. Contribution of Working Group I to the Fourth Assessment Report of the Intergovernmental Panel on Climate Change,, edited by: Solomon, S., Qin, D., Manning, M., Chen, Z., Marquis, M., Averyt, K. B., Tignor, M., and Miller, H. L., Cambridge University Press, Cambridge, United Kingdom and New York, NY, USA, 2007.

Shorthouse, C. A. and Arnell, N. W.: Spatial and temporal variability in European river flows and the North Atlantic oscillation, FRIEND '97 - Regional Hydrology: Concepts and Models for Sustainable Water Resource Management (Proceedings of the Postojna, Slovenia, Conference, September-October 1997), IAHS Publ., 246, 1997.

Thiéry, D.: Logiciel GARDENIA Version 6.0 - Guide d'utilisation, (GARDENIA software release 6.0 User's guide), BRGM Report, RP-52832-FR, 102 pp., 42 Figs., 2003, (in French).

Tisseuil, C., Vrac, M., Lek, S., and Wade, A.: Statistical downscaling of river flows, J. Hydrol, 385, 279-291, 2010.

van Roosmalen, L. V., Christensen, B. S. B., and Sonnenborg, T. O.: Regional differences in climate change impacts on groundwater and stream discharge in Denmark, Vadose Zone J., 6, 554-571, doi:10.2136/vzj2006.0093, 2007.

Vautard, R.: Multiple Weather Regimes over the North Atlantic: Analysis of Precursors and Successors, Mon. Weather Rev., 118, 2056-2081, 1990. 